\title{
Dikke lijven, Schone Kunsten; over kunst en onderwijs
}

Fictie als bron van kennis, schilderijen als propedeutische middelen, de arts en de kunst, geneeskunde en cultuur... Dat deze onderwerpen in dit tijdschrift bediscussieerd worden, kan de indruk wekken dat kunst in het medisch onderwijs een $\operatorname{plek}(\mathrm{je}$ ?) heeft verworven. En toch, geneeskunde en de schone kunsten, het blijft een vreemdsoortige combinatie.

In dit essay wil ik stilstaan bij de vraag wat - desondanks - de mogelijkheden en de beperkingen zijn van onderwijs met kunst en meer in het bijzonder met kunstvormen die dikte verbeelden.

Laat mij beginnen met de inzetbaarheid van kunst in het medisch onderwijs. Kunst is geen objectieve weergave van de werkelijkheid en kan daarom niet als vanzelfsprekend gebruikt worden voor kennisoverdracht noch voor attitudeonderwijs. Kennisoverdracht veronderstelt immers dat min of meer vaststaande feiten overgedragen kunnen worden. In de schone kunsten daarentegen, gaat het niet om 'de' waarheid, maar om mogelijke zienswijzen. Afbeelding en verbeelding lopen er door elkaar heen. Daardoor kan kunst geen concrete handvatten aanbieden over 'hoe te handelen'. Vandaar dat het evenmin vanzelfsprekend is kunst in attitudeonderwijs te gebruiken voor het aanleren van concrete vaardigheden in de medische praktijk.

En toch heeft kunst iets te bieden, niet ondanks maar dankzij de verbeelding. Verbeelding laat toe je in te leven, je in het perspectief van 'de ander' te verplaatsen. Het laat een ander dan je eigen perspectief zien. Het verbreedt je referentiekader.
Hoe flexibeler je bent in je denken, hoe makkelijker je ook omgaat met mensen met andere waarden, opvattingen of levenswijzen. In die zin kan kunst iets betekenen binnen het medisch onderwijs. Ik leg hierbij de nadruk op de voorwaardelijkheid: 'kan' en 'iets'. De impact van kunst op mensen is immers niet te categoriseren noch te voorspellen. Op de grenslijn tussen beeld en verbeelding valt er uit kunst te leren.

De overdracht in de kunst gebeurt op grond van het 'gevoel' van herkenning, het vermogen te beroeren, de eigenschap mensen te raken. En precies daarin is de kracht van de kunst gelegen. Neem bijvoorbeeld afbeeldingen/verbeeldingen van dikte in de kunst. Dikte is van alle tijden, zowel in 'werkelijkheid' als in de kunst. Denk aan de volumineuze vruchtbaarheidsbeeldjes van vele millennia geleden, aan de statige staatsieportretten of aan de met cellulitis doorspekte rubensbillen in barokschilderijen.

De betekenis van dikte is veel minder universeel. In de portretkunst uit de $16^{\mathrm{e}}$ en $17^{\mathrm{e}}$ eeuw bijvoorbeeld zijn 'de mannen van de macht' heel vaak dikker afgebeeld dan dat ze in werkelijkheid waren. Dikte stond voor macht. Van Hans Holbein's portret van Henri VIII weet men bijvoorbeeld dat zijn lichaamsomvang werd 'bijgevuld' om hem imposanter te laten lijken. Vandaag kunnen we ons moeilijk voorstellen dat Obama iets vergelijkbaars zou doen. Dikte wordt nu eerder geassocieerd met dom en 'dummy'. Waarden als gezondheid, evenwichtigheid en dynamiek worden niet meer toegeschreven aan dikte maar wel 
aan een afgetraind lijf. Vandaar dat Obama wellicht een foto verkiest bij de uitgang van de sportschool boven een aangedikt staatsieportret aan de muur van de 'oval office'.

Verbeelding van dikte in de kunst toont niet alleen aan dat dikte in sommige contexten staat voor macht en identiteit. Dikte in de kunst kan ook een esthetisch doel dienen. Ondanks het 'size-zero' schoonheidsideaal kunnen weldoorvoede naaktmodellen gewoon mooi zijn en verleiden. Denk aan de kronkelende dikke lijven in de werken van Lucian Freud. Of aan de fotocollectie van naakte dikke vrouwen van Laurie Toby Edison 'Woman in Large' (zie afbeelding 1). Andere hedendaagse kunstwerken zoals de kolossale wassen beelden van John Isaacs of de 'kussenkunst' van Candiani zetten dikte op een andere manier neer: in haar tastbaarheid. John Isaac, die zelf zeer dik is, laat in werken als 'I Can Not Help the Way I Feel' voelen hoe het moet zijn om zo door het leven te gaan (zie afbeelding 2). Candiani poneert dikte in haar werk 'Gordas' door eenvoudigweg grote kussens op elkaar te plaatsen. Hoe verschillend beide artiesten ook dikte verbeelden, zij hebben met elkaar gemeen dat zij de toeschouwer

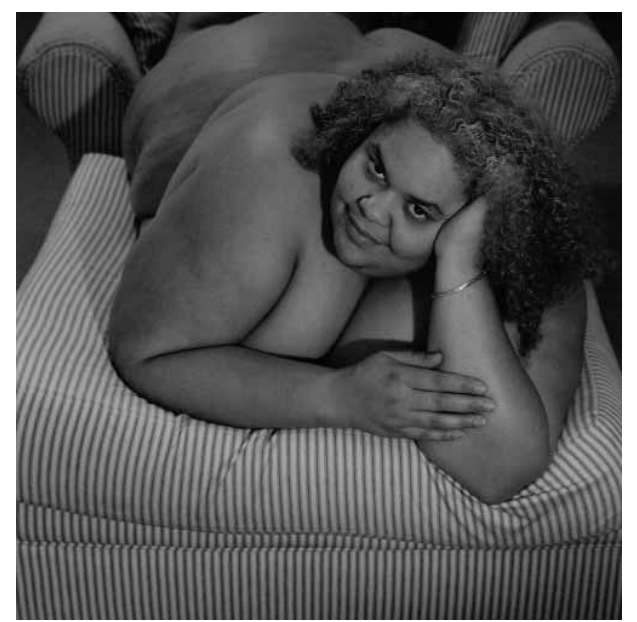

Afbeelding 1. 'Woman in Large' Laurie Toby Edison. dwingen als het ware 'even in de huid van dikte te kruipen' en zich in te beelden/ zich te verbeelden hoe dik zijn aanvoelt.

Meer dan de voorstellingen van dikte uit vroegere tijden, laten deze conceptuele werken voelen wat het betekent om dik te zijn. Alle kunst over dikte legt onze opvattingen en vooroordelen over dikke mensen bloot en op die manier worden we gewaar hoe dat slechts culturele, tijdgebonden constructies zijn. Op dat vlak heeft kunst het onderwijs iets te bieden. Het blootleggen van aannames is echter geen exclusieve eigenschap van kunst in het onderwijs. De meerwaarde van de kunst is het vermogen te laten aanvoelen wat het betekent voor dikke mensen om dik met die aannames te leven.

\section{Sofie Vandamme}

\section{De auteur:}

Mw. dr S. Vandamme is docent en onderzoeker bij de afdeling Filosofie en Medische ethiek van het Erasmus MC te Rotterdam. Haar onderzoeksinteresse gaat uit naar culturele presentaties van ziekte en lichamelijkheid. In 2007 publiceerde ze het boek 'Koele minaars. Medische verwoording en literaire verbeelding van ziekte in verhalen'. E-mail: s.vandamme@pandora.be

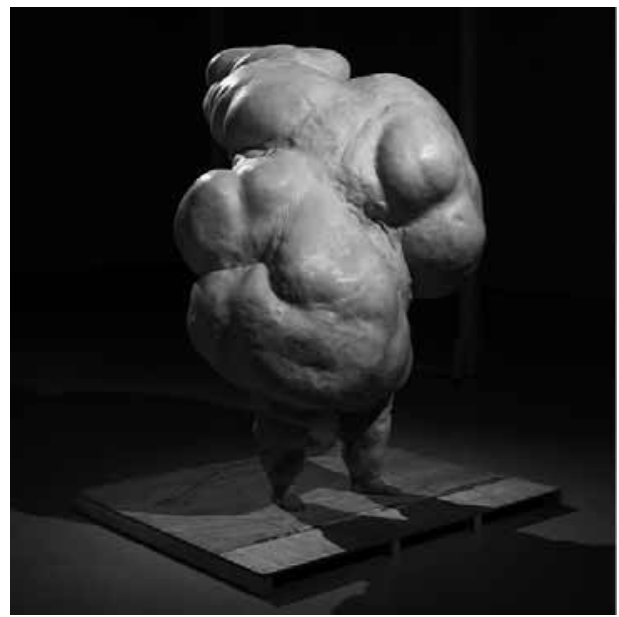

Afbeelding 2. 'I Can Not Help the Way I Feel' John Isaac. 